Athens Journal of Law - Volume 4, Issue 1 - Pages 67-90

\title{
A Revisit of the Institutional Machineries for Prosecuting Individuals for International Crimes: Charting the way Forward
}

\author{
By Babalola Abegunde*
}

Law has undoubtedly, exerted considerable influence on the shaping of the human destiny. Indeed, it is no exaggeration to aver that the evolution law has been a critical moment in human experience. Without it, it is practically impossible to contemplate human society or as Roberto Unger once put it, "law is the glue that holds society together". Against the foregoing, several institutions have emerged from national, regional to global levels for the investigation of atrocities and prosecution of same. This paper, a desk-based, doctrinal research, examined various institutions established for the prosecution of individuals who commit international crimes. It relied on both primary and secondary sources of data which were subjected to content and contextual analysis. It also examined the prosecution of international crimes before the Domestic court, as well as some inherent challenges and prospects of such practice. This paper is significant because, it will not only fill some specific gaps in this particular area, rather, it will enrich existing literatures, generally, on public international law. It is the finding of this paper, that despite plethora of institutions fighting against impunity from national, regional and global axis, and the results recorded, a lot still needs to be done. More so, that the criminal individuals and organisations have not stopped devising new strategies against humanity. It concludes by proffering some recommendations.

Keywords: Institutions; Individual Responsibility; International Law; Prospect; Challenges; Criminal Justice; International Criminal Tribunals.

\section{Introduction}

Several institutions of international criminal law have existed in history. Some precedents of institutional frameworks can be found in the time before the First World War. However, it was after the war that a truly international criminal special tribunal was envisaged to try perpetrators of crimes committed in this period. Thus, the Treaty of Versailles states that an international tribunal was to be set up to try Emperor Kaiser Wilhelm II of Germany. In the event however, Kaiser was granted asylum in Netherlands.

After the Second World War, the Allied Powers set up an international tribunal to try war crimes, and crimes against humanity committed under the

\footnotetext{
${ }^{*}$ PhD, Senior Lecturer and Head, Department of Public Law, Faculty of Law, Ekiti State University, Ado- Ekiti, Nigeria. Email: babalolaabegunde@ yahoo.com.
} 
Nazi regime ${ }^{1}$. Since then, several institutions have evolved across the globe some of which are going to be examined shortly.

\section{Global Institutions for Prosecuting Individuals}

The following global institutions have helped to put an end to the era of impunity, where individuals were portrayed as lacking in any international capacity.

\section{The Nuremberg Tribunal}

The Nuremberg Trials were a series of trials or tribunals, most notable for the prosecution of prominent members of the political, military, and economic leadership of Nazi Germany after its defeat in Second World War. The trials were held in the city of Nuremberg, Germany, from 1945 to 1946 at the Palace of Justice. Twenty four major war criminals and six criminal organisations were indicted for conspiracy to commit crimes against peace, planning, initiating and waging wars of aggression, war crimes and crimes against humanity. Those indicted included Adolf Hitler's cabinet, the leadership of the Nazi party, the Gestapo, the General Staff and High Command of the German armed forces (OKW), the Schutzstaffel (SS) and Sicherheitsdienst (SD), and the Stumabteillung (SA). ${ }^{2}$ Of the 24 members of the Nazi leadership, three were acquitted ${ }^{3}$, twelve were sentenced to death by hanging ${ }^{4}$ and the rest were handed prison sentences ranging from ten years to life ${ }^{5}$. On October 16, 1946, ten of the twelve men were hanged.

\section{Tokyo Tribunal}

A similar tribunal was established for Japanese war crimes. The International Military Tribunal for the Far East a.k.a. Tokyo Tribunal was convened on May 3, 1946 to try the leaders of the Empire of Japan for three types of crimes: "Class

\footnotetext{
${ }^{1}$ Carter \& Trimble (1995) at pp. 1430 - 1434. There is no complete list of the thousands of war crimes trials held following Second World War. See, 'What Were the Nuremberg Trials ?' available at, http://en.wikipedia.org/wiki/Nurembergtrials

${ }^{2}$ Ibid

${ }^{3}$ Acquitted are: Hans Fritzsche, Franz Von Papen and Dr. Hjalmer Schacht

${ }^{4}$ Sentenced to death by hanging were: Martin Bormann, (Nazy Party Secretary), Hans Frank, Wilhelm Frick, (Minister of Interior) Hermann Goring, Alfred Jodi, Ernst Kaltenbrunner, Wilhem Keitel, Joachim Von Ribbentrop, Alfred Rosenberg, Fritz Sauckel, Arthur Seyss-Inquant, Julius Streicher. It should be noted that Herman Georing committed suicide the night before his execution, while Martin Bormann was tried in absentia.

${ }^{5}$ Karl Donitz got 10 years jail term, Walther Funk Minister of Economics got life jail, Rudolf Hess got life jail, Baron Konstantia Von got 15 years jail, Erich Raeder got life jail, Baldur Von Schirach got 20 years jail, Albert Speer got 20 years jail. The Nuremberg Trials resulted in 24 executions, 128 imprisonments and 35 acquittals.
} 
A" (Crimes Against Peace), "Class B", (War Crimes), and Class "C" (Crimes Against Humanity), committed during World War II $^{6}$.

Twenty eight Japanese military and political leaders were charged with Class A crimes out of which two died of natural cause during trial ${ }^{7}$. Seven others were sentenced to death by hanging and they were executed at Sugamo prison in Ikebukuro on December 23, $1948^{8}$. Sixteen more were sentenced to life imprisonment ${ }^{9}$. Shigenori Togo got 20 year jail term and died in prison in 1949, Mamoru Shigeitsu got 7 years jail.

It is pertinent to mention that the two International Military Tribunals (Nuremberg and Tokyo) tried a small number of major war criminals, while other tribunals tried so-called minor war criminals. There were also a number of trials held by nations against their own citizens. German Courts prosecuted thousands of war criminals either not tried by the Allies or tried by them and acquitted $^{10}$.

It is instructive to mention that irrespective of the criticisms levelled against Nuremberg and Tokyo Trials as "victor's justice", indictment being ex-post facto and retrospective, yet they represent a significant milestone in the jurisprudence of international criminal justice and fight against impunity.

\section{Yugoslavia Tribunal}

A milestone in the development of international criminal law occurred in 1993 with the establishment of the International Criminal Tribunal for the former Yugoslavia (ICTY). It was established under Chapter VII of the UN Charter ${ }^{11}$. ICTY benefited from the Nuremberg legacy. By Article $1^{12}$ of the statute of the ICTY, the Tribunal shall have power to prosecute persons responsible for various violations on international humanitarian law committed in the territory of the former Yugoslavia since 1991.

The maximum sentence it can impose is life imprisonment ${ }^{13}$. The jurisdiction of domestic courts is recognized to be concurrent with that of the Tribunal. Article $7^{14}$ of the statute of ICTY contains provisions dealing with individual criminal responsibility. Article 9 (2) of the ICTY gives the Tribunal primacy over national courts.

\footnotetext{
${ }^{6}$ Bass (2000); Maga (2001).

${ }^{7}$ Matsuoka Yosuke and Nagano Osami.

${ }^{8}$ Those who received death sentence are General Kenji Doibara, (Air Force Commander); Baron Koki Hirota (Foreign Minister); General SeishiroItagaki (War Minister); General Heitaro Kimura; General Iwane Matsui; General Akira Muto and General HidekiTojo.

9 Sixteen people got life jail. "Judgment: International Military Tribunal for the Far East". http://www.ibiblio.org/hyperwar/PTO/IMTFE/index.html.

${ }^{10}$ Carter \& Trimble (1995) at pp. 1432-1434. For a detailed account of the proceedings of this Tribunal, see Pritchard \& Zarde (1981).

${ }^{11}$ Jallow \& Bensouda (2008), at pp. 15-54 and $34-35$. See also United Nations Security Council Resolution 82725 May 1993. See generally Gallagher (2005); Hagan, Levi \& Feralles (2006).

${ }^{12}$ Article 11 Statute of the ICTY

${ }^{13}$ Article 12 Statute of the ICTY

${ }^{14}$ Article 7 Statute of the ICTY
} 
The stated mission of the ICTY is four fold: (i) to bring to justice persons allegedly responsible for the serious violations of international humanitarian law, (ii) to render justice to the victims (iii) to deter further crimes, and (iv) to contribute to the restoration of peace by holding accountable persons responsible for serious violations of international humanitarian law ${ }^{15}$.

Milosevic was indicted while in office as a serving President and arrested by the Serbia Police on April 1, $2001^{16}$.

According to Carla-Del-Poute, the war crime tribunal prosecutor:

The trial of Milosevic proves that no individual is above the law. She said further, the international criminal tribunal was based on the application of the international humanitarian law, hence, Milosevic was being prosecuted on the basis of international individual criminal responsibility. No state or organisation is on trial. This is a criminal trial ${ }^{17}$.

Accordingly, no one is beyond the reach of international justice. ${ }^{18}$ Milosevic was indicted as a serving head of State but at the time of his trial he was no longer a President. ${ }^{19}$. As at December 2003, more than twenty people had been convicted by the Tribunal and two had been acquitted ${ }^{20}$. The convicted persons who were serving prison terms included Erdemovic ${ }^{21}$ who pleaded guilty. Tadic is serving a life sentence ${ }^{22}$. Also, Darko Mrdja $^{23}$ was convicted by the ICTY and his defence of superior order was refused. In Prosecutor v Vidoje Blagojevic and Dragan Jokic ${ }^{24}$ the court convicted the accused. Radislav Krstic, is currently serving a 35 years sentence in the United Kingdom having been convicted of aiding and abetting genocide among others

Various countries signed agreement with the United Nations to carry out custodial sentences 25 .

On its website, the ICTY summarizes some of its "core achievements": thus (1) Strengthening the shift from impunity to accountability, (2) establishing the facts regarding the atrocities committed in the former Yugoslavia, (3) bringing

\footnotetext{
15 Jallow \& Bensouda (2008) at p. 35

${ }^{16}$ The indictment of Milosevic et al case 17-99-37-1, ICTY, May 24, 1999

${ }^{17}$ Del Ponte (2000).

${ }^{18}$ CNN News 28-6-2001.

${ }^{19}$ Nouwen (2005).

${ }^{20}$ Fact Sheet on the ICTY Proceedings, December 29, 2003.

21 Prosecutor v Endemovic, Case No IT-96-22-A. Appeal Chambers 7 October 1997 where Endemovic was convicted and his defence of superior order was refused.

${ }^{22}$ Prosecutor $v$ Tadic case No IT-94-1 Appeal Chambers 15 July, 1999

${ }^{23}$ Prosecutor v Mrdja case No IT-02-59-S. Trial Chambers, 31 March, 2004.

${ }^{24}$ Prosecutor v Blagojevic and Jokvic Case No IT-02-60 Trial Judgment, Trial Chamber 17 January, 2005.Blagojevic was a colonel in the Army of Republika Srpska and Commander of the Bratunac Brigade. He was sentenced to 18 years imprisonment for complicity in genocide and other inhuman acts. The prosecutor however challenged the sentence, characterizing it as manifestly inadequate. Dragan Jokic a major in Republika Srpska was sentenced to nine years imprisonment. See also Gallaghar (2005)..

${ }^{25}$ Available at http://www.enwikipedia.org/wiki/internationalcriminallaw
} 
justice to thousands of victims and giving them a voice, (4) accomplishments in international law, and (5) strengthening the rule of law ${ }^{26}$.

\section{Rwandan Tribunal}

The International Criminal Tribunal for Rwanda (ICTR) was established by the Security Council acting under Charter VII of the Charter of the UN in order to prosecute people responsible for the Rwandan Genocide and other serious violations of the International Law in Rwanda or by Rwanda citizens in nearby states, between $1^{\text {st }}$ January and $31^{\text {st }}$ December $1994^{27}$.

The trial of Jean-Paul Akayesu ${ }^{28}$ began in 1997. Akayesu judgment was innovative in its affirmation of rape as an international crime, and a constituent act of genocide. Importantly, after Nuremberg, ICTR was the first international criminal tribunal to convict a head of government. The court convicted Jean Kambanda $^{29}$, the Prime-Minister of Rwanda from April - July 1994 of genocide.. Nahimana, "the Media Case", was the first post-Nuremberg case to examine the line between freedom of expression and incitement to international crimes ${ }^{30}$. This case was the first pronouncement by an international tribunal on such issues after the case of Julius Streicher at Nuremberg.

The ICTR ordered punishment up to life imprisonment but does not impose death sentence ${ }^{31}$. The convicts are to serve their sentences in prisons in Rwanda or in other countries as arranged by the Tribunal ${ }^{32}$.

ICTR also provides examples of cooperation on the African continent and from states outside Africa. Alleged perpetrators of the crimes were arrested, among others, through cooperation with several African and non-African countries. Arrests took place among others in, Cameroon, Kenya, Benin, Belgium, Kenya, Zambia, South Africa, Cote-d'Ivoire, Uganda, Mali, Switzerland, Senegal, Namibia and Garbon ${ }^{33}$. This regional cooperation indicates willingness and ability of African States to cooperate on International Criminal Investigation and Prosecution. ICTR has also handed 30 case files to the government of Rwanda for

\footnotetext{
${ }^{26} \mathrm{http}: / /$ www.un.org/icty/glance-e/index.html

${ }^{27}$ UN Security Council Resolution 955. S. RES 955, 1994 on 8, November, 1994; Human Rights Watch Report on Rwandan Genocide. See also the United Nations and Rwanda, (A UN publication) pp. 55 - 56; Jallow \& Bensouda,(2008) at pp $35-37$

${ }^{28}$ Prosecutor v Akayesu, Case No ICTR-96-4-T delivered 2 September, 2008.

${ }^{29}$ Prosecutor v Jean Kambanda, Case No ICTR 97-23.S. delivered on 4 September, 2008

${ }^{30}$ See the ICTR's website at, http://69:94.11.53/ENGLISH/factsheets/detainee.htm.

${ }^{31}$ Article 23 (1) statute of ICTR

${ }^{32}$ Article 26 statute of ICTR

${ }^{32}$ Article 26 statute of ICTR

${ }^{32}$ Article 26 statute of ICTR

${ }^{33}$ Fighting Genocide, Houston Chronicle, August 22, 1998, see also http://69:94.11.53/ENHLI $\mathrm{SH} / \mathrm{factsheets/detainee.htm.} \mathrm{For} \mathrm{instance,} \mathrm{Jean} \mathrm{Kambanda} \mathrm{was} \mathrm{arrested} \mathrm{by} \mathrm{Kenyan} \mathrm{authority} \mathrm{on}$ the basis of a formal request submitted by the prosecutor to ICTR and handed over to ICTR. Also, on 29 September, 2002, one of the main Rwandan genocide suspect, Col. Tasisu Renzau, a Mayor and Prefect of Kigali in 1994 who was also the Leader of the Army for Liberation in Rwanda (AFLR), responsible for killing American soldiers in 1999 was arrested in the Democratic Republic of Congo (DRC) and handed over to the Tribunal in Arusha.
} 
prosecution before the Rwanda national courts. Other judgments of the Court abound $^{34}$.

\section{Special Court for Sierra-Leone (SCSL)}

Crimes against humanity and war crimes were committed during a noninternational armed conflict between rebel forces and the armed forces of the government of Sierra-Leone from 1991-1992. The rebel factions and government forces that participated in the armed conflict included the Revolutionary United Front (RUF), the Armed Forces Revolutionary Council (AFRC), the AFRC/RUF, and the Civil Defence Forces (CDF) ${ }^{35}$.

Following the crimes committed during the war, the government of SierraLeone requested the United Nations to assist in establishing a court that would prosecute and punish persons who bear the greatest responsibility for the international crimes ${ }^{36}$.

The basis of the SCSL is its statute and the agreement concluded between the UN and the government of Sierra-Leone ${ }^{37}$. Unlike the ICTY and the ICTR which are purely international tribunals established under Chapter VII of the Charter of the UN, the SCSL was established under Chapter VI of the Charter of the UN. The SCSL is a hybrid (mixed) criminal court ${ }^{38}$. It is composed of international and national judges, lawyers and other appointed staff. It applies international law and domestic law.

The SCSL has competence to render justice to the victims and persons found guilty of serious violations of humanitarian law and Sierra-Leonean law ${ }^{39}$.

The first thirteen indictments were approved by the Court on 7 March, $2003^{40}$. On 27 January 2004, the prosecutor of the SCSL consolidated the cases

\footnotetext{
${ }^{34}$ Prosecutor v Rutagand, Case ICTR-96-3. Judgment Sentence 6 December 1999; Prosecutor V Musema case ICTR 96-13-T- Judgment and Sentence 27 January, 2000; Prosecutor v Kayishema and Ruzindana case ICTR-95-I-T Judgment and Sentence 21 May 1999, Prosecutor V Kunarac case IT-96-23 Appeal 12 June, 2002; Prosecutor v Muhimana, Case ICTR-95-13-T. Judgment 28 April 2005; Gacumbitsi v Prosecutor, Case ICTR-2001-64-A, Judgment 7 July 2006.

${ }^{35}$ See Government of Sierra-Leone Truth and Reconciliation Commission Report (2004); Murungu (2011) at pp. 97-117.

${ }^{36}$ On 12 June 2000, Sierra-Leone President Ahmad Tejan Kabbah wrote a letter to the UN Secretary General Kofi-Annan asking for the international community to try those responsible for crimes during the conflict. On 14 August 2000, the UN Security Council adopted Resolution 1315 as a prelude to the creation of the Special Court. Article 1(1), and 6(5) SCSL.

${ }^{37}$ Statute of the SCSL UN Doc.S/2000/915; The Special Court Agreement (Ratification) Act 9 of 2002 Supplement to the Sierra-Leone Gazette, CXXXIII, (22) 25 April 2002.

${ }^{38}$ See Generally Bhoke (2008); Jallow \& Bensoula (2008) at pp. 38-39.

${ }^{39}$ Prosecutor v Norman, Fofana and Kondewa case SCSL-04-14-T

40 See Proseuctor v Koroma (Case SCSL-03-03); Prosecutor v Bockarie (case SCSL 03-04); Prosecutor v Sankoh (Case SCSL-03-02), Prosecutor v Norman (case SCSL-03-08); Prosecutor v Fofana (case SCSL-03-1); Prosecutor v Kondewa (case SCSL-03-12); Prosecutor v Sesay (case SCSL-03-05); Prosecutor v Kallon (case SCSL-03-07); Prosecutor v Gbao (case SCSL-03-09); Prosecutor v Brima (Case SCSL-03-06); Prosecutor v Kamara (case SCSL-03-10); Prosecutor v Kanu (Case SCSL-03-13); Prosecutor v Taylor (Case SCSL-03-01). See the Official Site for the Special Court (http://www.sc-sl.org/). All these accused participated in joint criminal enterprise to exercise control over Sierra-Leone. See Danner \& Martinez, (2005).
} 
of nine accused persons under the CDF Trial ${ }^{41}$, the RUF Trial ${ }^{42}$ and the AFRC Trial $^{43}$. Charles Taylor was tried separately ${ }^{44}$. They were all convicted for war crimes and crimes against humanity ${ }^{45}$. The Appeals Chamber sentenced Issa Sesay to 52 years imprisonment, Morris Kallon to 40 years and Augustine Gbao to 25 years $^{46}$.

On 19 July, 2009, the Trial Chamber of SCSL delivered a single sentence of 50 years for Tamba Brima, 45 years for Bazzy Kamara and 50 years for Borbor Kanu ${ }^{47}$. On 31 October, 2009 all eight persons convicted and sentenced by the SCSL (the prisoners) were transferred to Rwanda to serve their sentences ${ }^{48}$. They are currently incarcerated in Mpanga Prison in Rwanda under an agreement signed between the SCSL and Rwanda in March 2009. Charles Taylor was convicted on Thursday26 April 2012 in a historic verdict for international justice and on 30 May 2012, the SCSL sentenced sixty four years old Taylor to 50 years imprisonment ${ }^{49}$.

Like the ICTR, the SCSL has contributed in significant ways to the jurisprudence of international criminal law. For instance, the decision of SCSL in Prosecutor v Brima, Kamara and Kanu was the first judgment of the SCSL and the first time an international court ruled on charges relating to child soldier or forced marriage, and the first time an international court delivered guilty verdict for military conscription of children ${ }^{50}$. Therefore, this was a landmark decision, by which the SCSL has created a major legal precedent in international criminal law. The contribution and legal precedent of the Court to the development of international criminal law can also be seen in the SCSL decisions on immunity of state official ${ }^{51}$ sexual violence and forced marriage.

${ }^{41}$ Prosecutor v Norman, Fofuna and Kondewa Civil Defence Forces (CDF) Trial (Case SCSL04-14-PT) 5 Feb 2004

${ }^{42}$ Prosecutor v Sesay, Kallon, and Gbao, Revolutionary United Front (RUF) Trial (case SCSL04-15-PT) 13 May, 2004.

${ }^{43}$ Prosecutor v Brima, Kamara and Kanu, AFRC Trial (Case SCSL-2004-16-PT) 18 February 2005.

${ }^{44}$ Prosecutor v Taylor (case SCSL-2003-01-1), 3 March 2003

${ }^{45}$ Prosecutor v Fofana \& Kondewa (Case SCSL-04-14-A) Appeal Judgment 28 May, 2008 Para 110. (http://www.sc-sl.org/CDF-Trial.html)

${ }^{46}$ Prosecutorv Sesay, Kallon\&Gbao (Case SCSL-04-14-A) Appeal Judgment 25, October, 2009.

${ }^{47}$ Prosecutor v Brima, Kamara and Kanu (Case SCSL-04-16-T) Sentencing Judgment 19 July, 2007 (http:' 'SC-SL.org(AFRC-Trial.html).

${ }^{48}$ Special Court Prisoners Transferred to Rwanda to serve their sentences Special Release, SCS1, 31 October 2009.

${ }^{49}$ World Court Convicts Taylor of War Crimes, World News, PUNCH Friday April 27, 2012, p 53; Leke Baiyewu, Taylor: Lesson for African Tyrants, PUNCH, Sunday June 3, 2012, P.11

${ }_{50}^{5}$ See SCSL website: http://www.Sc-SL.org/Press/Press release-0620007.pdf .

${ }^{51}$ See Prosecutor v Taylor (Supra) para 45-53. The implication of Taylor's case for international justice is that Taylor's indictment has established a very fundamental principle to the effect that a serving Head of State is not immune from prosecution. It is the first judgment against a former head of state by a world court since the World War II Nuremberg Trials. See generally, http:enwikipedia.org/wiki.-special-Court-for-Sierra-Leone; Adedamola (2005); Nouwen (2005); Deen-Racsmany (2005). 


\section{The Iraq Special Tribunal}

The statute of the Iraq Special Tribunal ${ }^{52}$ of 10 December 2003 authorized the establishment of the Iraq Tribunal charged with the responsibility of trying "any Iraqi national or resident of Iraq" accused of genocide, crimes against humanity or war crimes. The influence of the U.S. - British Coalition Provisional Authority (CPA) on the design of post - conflict justice in Iraq and the concomitant pressure for local ownership in the post-Saddam era led to the creation of an internationally-assisted Special Tribunal. The status of the Special Tribunal is unique. It has both Trial and Appeals Chambers, with domestic judges formally in charge of the trials ${ }^{53}$.

The Tribunal prosecuted and sentenced Saddam Hussein to death, which sentence was upheld by the Appeals Tribunal on 27 December, 2006. Saddam was convicted of war crimes, torture, genocide and crimes against humanity committed during his 24 years of bloody dictatorship in Iraq through his Ba'ath party $^{54}$. Saddam Hussein was hanged on 30 December 2006.

\section{Extraordinary Chambers in the Courts of Cambodia (ECCC)}

In 1997, the government of Cambodia requested the UN to assist in establishing a court to prosecute the senior leaders of the Khmer-Rouge ${ }^{55}$, a regime that came to power on 17 April 1975 and was overthrown on 7 January 1979. The regime was allegedly involved in a large scale perpetration of atrocities in Cambodia. Subsequently, in 2001, the Cambodian National Assembly enacted a law to create a court- the Extraordinary Chambers in the Courts of Cambodia (ECCC) for the prosecution of crimes committed during the period of Democratic Kampuchea. It comprises both Western and Cambodian judges. Importantly, ECCC is the first hybrid tribunal to be established in a civil law system

The Court, a joint Cambodian - United Nations Court commenced the trial of five former members of the Ultra-Maoist Khmer-Rouge group on war crimes charges $^{56}$.

\footnotetext{
${ }^{52}$ Article 1 Statute of Iraq Special Tribunal dated 10 December 2003

${ }^{53}$ Stahin (2005).

${ }^{54}$ Chemical Ali, Two others to Die by Hanging, The Punch, Monday June 25, 2007, p. 43. On the order of Iraqi Special Tribunal Barzan Ibrahim Saddam's half-brother was beheaded in January 2007, Awadhamed al-Banda was executed along with Barzan Ibrahim, Taha Yasin Ramadan was executed on 20 March 2007. Others who were sentenced to death by Iraq Special Tribunal include Sultan Hashim former Defence Minister and Hussein Rashid al-Tikrit ex-Republican Guard Head. They were all found guilty of war crimes and crimes against humanity. Farhan-al-Jibouri, exMilitary Commander and Saber Abdul Aziz, ex-Intelligence Chief were both sentenced to life imprisonment for war crimes and crimes against humanity. See generally PUNCH Newspaper of June 25, 2007, p. 43. The NATION Newspaper, Wednesday 21 March, 2017.

${ }^{55} \mathrm{http} / / /$ www.ccc.gov.kh/english.about_eccc.aspx

${ }^{56}$ They are kaing Guek Eav (alias Duch), Nuon Chea, leng Sary, Ieng Thirith and Khieu Samphan. Duch has been convicted and sentenced to life imprisonment since February 2012.)
} 


\section{East Timor Special Panels}

The Special Panels of the Dili District Court is a hybrid tribunal with Timorese and international staff. It was created in year 2000 by the UN Transitional Administration in East Timor (UNTAET) ${ }^{57}$. The Special Panels functioned in the period from 2000 to 2006. The UNTAET replicates the individual criminal responsibility provision of the Rome statute of the ICC. One of the indictments issued by the prosecutor for serious crimes charges a variety of senior individuals including Abilo Jose Osorio Soares, the former Governor of East Timor, with crimes against humanity ${ }^{58}$. Other indictments before the Special Panel abound ${ }^{59}$. On 5 August 2003, the ad hoc court of East Timor convicted Major General Adam Damiri and sentenced him to three years imprisonment ${ }^{60}$.

\section{Other Ad-hoc Institutional Frameworks}

Apart from the foregoing, a host of other institutional mechanisms for individual criminal responsibility have been established at the international scene. They include the Sri Lanka War Crimes Tribunal; Bangladesh War Crimes Tribunal, the Security Council backed Special Tribunal for Lebanon which was set up to try those allegedly responsible for the assassination of the then Lebanese Prime Minister Rafik Hariri and 22 others in a massive car bombing in Beirut. According to the statute, the tribunal has concurrent jurisdiction with Lebanon's national courts, but primacy over those courts within its jurisdiction. The tribunal has power to impose life sentence. There is also the Kosovo Special Court, the Special War Crimes Chambers in Bosnia and Herzegovina, War Crimes Chambers of Sarajevo, Nanking War Crimes Tribunal in China, and Khabarovsk War Crimes Trial in former Soviet Union ${ }^{61}$. All these collectively help to build and advance the jurisprudence of international criminal justice. They help to strengthen and promote the principle of accountability as against impunity.

\footnotetext{
${ }^{57}$ See Regulation No 2000/15 on the Establishment of Panels with Exclusive Jurisdiction over serious criminal offences. See Section 14.3 (d) UNTAET/Reg/2000/15 (6 June, 2000\}.

${ }^{58}$ Prosecutor $v$ Wiranto et al, Indictment Count one, P. 36 UN MISET (Special Panel for Serious Crimes, Feb. 22, 2003).

${ }^{59}$ Prosecutor v Sormento et al, indictment II, August 7, 2001, available at http://www.jsmp.mi nihub.org/courtmonitoring/spsccaseinformation 2000.htm. Indictments for almost 400 persons were issued. Some 55 trials involving 88 accused persons were held by the Special Panels, Four persons were acquitted and 84 were convicted. See Jallow \& Bensouda op. cit. pp 37-38

${ }^{60} \mathrm{http}: / /$ www.et.an.org/etanpdf/pdf3/No542617.pdf This decision has been widely condemned. East Timor Action Network (ETAN) urged the UN to guarantee real justice for East Timor by establishing an international tribunal. According to John Miller, spokes person for ETAN "the punishment does not fit the crime". An international tribunal is needed if the many victims of war crimes and crimes against humanity in East Timor are to see genuine justice. The East Timorese deserves no less than Iraqis, Rwandans and Bosnians.

${ }^{61}$ http://www.enwikipedia.org
} 


\section{International Criminal Court (ICC)}

International Criminal Court (ICC) was established as a response of the human family to gross human rights violations of such magnitude and barbarity as to shock human conscience and to warrant the response of the international community as a whole ${ }^{62}$. The ICC symbolizes the principle of individual criminal responsibility for those responsible for the 'most serious' human rights violations and was established as a permanent institution to ensure the punishment of such individuals. From the stand point of rule of law and justice, the ICC is one of the greatest achievements of the twentieth century.

By Article 1, the ICC has jurisdiction over "persons responsible for the most serious crimes of international concern" 63 and is to be "complementary to national criminal jurisdictions" Court are genocide, ${ }^{65}$ crimes against humanity, ${ }^{66}$ war crimes ${ }^{67}$ and crime of $\operatorname{aggression}^{68}$.

To date, the ICC has opened investigation into several situations in Africa. Two were referred by the United Nations Security Council (Darfur and Libya), and two were begun proprio-motu by the Prosecutor (Kenya and Cote d'Ivoire) ${ }^{69}$. Right now, both the President and Vice-President of Kenya (Uhuru Kenyatta and Williams Ruto) among others are standing trial before the ICC for crimes against humanity committed in 2007

ICC's first trial of Congolese militia leader, Thomas Lubanga, began on 26 January 2009 and on March 14, 2012, the ICC found him guilty of war crimes (using child soldiers) among others ${ }^{70}$. The ICC's detention centre houses German Katanga $^{71}$, Mathieu Ngudjolo Chui ${ }^{72}$, and Jean-Pierre Bemba ${ }^{73}$ among others who are standing trial before the Court ${ }^{74}$. One of the great innovations of the statute of the ICC and its Rules of Procedure and Evidence is the series of rights granted to victims. For the first time in the history of international criminal justice, victims have the possibility under the statute to present their views and observations before the court. Article $43(6)^{75}$ of the Rome Statute establishes a

\footnotetext{
${ }^{62}$ Mugwanya (2006).

${ }^{63}$ ICC Article 1.

${ }^{64}$ ICC Article 17.

${ }^{65}$ ICC Article 5(1)(a).

${ }^{66}$ ICC Article 5(1)(b).

${ }^{67}$ ICC Article 5(1)(c).

${ }^{68}$ ICC Article 5(1) (d)

${ }^{69}$ Available at http://www.icc-cpi.int See Prosecutor v Uhuru Kenyatta, Prosecutor $v$ William Ruto. Available at en.m.wikipedia.org/wiki/international_criminal_court

${ }^{70}$ Prosecutor v DyiloLubanga, ICC-01/04-01/06, 29 January, 2007, para 261 - 263, available at www.icc-cpi.int. Also available at http://www.lubangatrial.org/2012/06

${ }^{71} \mathrm{http} / / / \mathrm{www} . \mathrm{ICC}-\mathrm{CPI}-\mathrm{int}$. Katanga also known as Simba is the former leader of the Patriotic Resistance Force in Ituri, DRC. See en.wikipedia.org/wiki/German_katanga

${ }^{72}$ Ngudjolo is also a Congolese War Lord. See ICC website:www.kc-cpi.int

${ }^{73} \mathrm{Bemba}$ is a former Vice President in the Democratic Republic of Congo see en.wikipedia. org/Jean-Pierre Bemba

${ }^{74}$ www.icc-cpi.int

${ }^{75}$ Article 43 (6) statement of the ICC
} 
Victims and Witness Unit to provide protective measures and security arrangements for victims and witnesses who appear before the court. Article $79^{76}$ thereof also establishes a Trust Fund to make financial reparations for victims and their families.

\section{Regional Courts and Commissions}

Regional organisations have established human rights courts to help promote international standards in their regional and domestic legal systems. These courts are not criminal tribunals, but they do allow individuals often with the support of human rights organisations to appeal to them when their governments fail to observe human rights obligations. With its forty-seven member states, the Council of Europe's European Court for Human Rights is the most prominent and successful example. It has also promoted the pursuit of justice at the national level $^{77}$. The Organisation of American States Inter-American Court for Human Rights, with jurisdiction over twenty-five states in the Americas (not including the United States and Canada), has helped encourage the development and use of domestic mechanisms in Columbia, Argentina, Guatemala and elsewhere ${ }^{78}$.

Regional mechanisms in Africa- include the African Court of Justice and Human Rights (ACJHR), the African Commission on Human and People's Rights (ACHPR), the East African Court of Justice (EACJ) and the Economic Community of West African States (ECOWAS) Court of Justice. It is pertinent to mention that the African and Asian mechanisms are at their early stages of developing similar rules in their own environments ${ }^{79}$.

Regional Courts offer advantages that international bodies cannot always provide: proximity to countries in conflict, and understanding of local trends and legal cultures as well as personnel with strong ties to the national legal institutions ${ }^{80}$.

\footnotetext{
${ }^{76}$ Article 79 Ibid.

${ }^{77}$ Individuals may claim that a national government, within the jurisdiction of one of the Courts, has denied their right to a remedy for a violation of a specific right (for example, the right to life or the prohibition against torture). See, for example, Article 13 of the European Convention on Human Rights. In turn, the European and Inter - American Courts have pressed for effective investigations and where warranted, prosecutions to provide such remedies. See for example, European Court of Human Rights, "Khashiyev\&Akayeva v Russia", App. Nos 57 942/00 \& 57945/00, February 24, 2005, http://www.echr.coe.int . See also, Kaye (2011)..

${ }^{78}$ The Role of the IACHR is complex. See Cavallaro \& Brewer (2008).

${ }^{79}$ The first decision of the African Court of Human Rights was issued on March 25, 2011, against Libya. See Human Rights Watch, " Libya: African Rights Court Issues first Ruling Against a State", March 30, 2011, http://www.hrw.org/en/news/2011/03/30/libya-african-rights-court-is sues-first-ruling-against-state. For human rights initiative among ASEAN nations, see http: www.aseanhrmech.org.

${ }^{80}$ Kaye (2011) at p. 10.
} 


\section{United Nations Bodies}

Several institutions within the UN system investigate alleged atrocities, report on their findings, recommend further investigation and prosecution, and otherwise trigger international action before, during, and after conflict. UN peacekeeping forces increasingly support accountability efforts. The United Nations Organisation Stabilisation Mission in the Democratic Republic of Congo (MONUSCO), for instance, supports mobile courts in the east of the country, bringing judges to otherwise remote crime scenes to address crimes of sexual violence $^{81}$.

The UN High Commissioner for Human Rights, UN Special Rapporteurs, and ad-hoc fact-finding missions provide detailed information on abuses, usually through reports to UN political bodies ${ }^{82}$. The Human Rights Council, whose work is often highly politicized, may draw attention to atrocities through votes to censure governmental behaviour ${ }^{83}$.

Treaty bodies outside the UN system - such as the Human Rights Committee of the International Covenant on Civil and Political Rights and the Committee against Torture collect information that, like all of these institutions can feed into national efforts and spur local, regional and international actors to investigate and prosecute abuses.

\section{Domestic Institutions and International Crimes}

Prior to the Creation of the ICC in 2002 and the advent of the ad-hoc criminal tribunals such as the Special Court of Sierra-Leone (SCSL) and International Criminal.

Tribunal for Rwanda ICTR, it was left to the domestic criminal courts of states to investigate and prosecute international crimes. On several occasion, this has been done by relying wholly or partly on the principle of universal jurisdiction.

Some conducts violate not only the domestic legal order of a state, but also international legal order. That is why certain crimes are designated as international crimes. States may thus exert jurisdiction over the perpetrators of such crimes on the basis that the crime committed is a crime against all human kind and in respect of which an individual places himself beyond the protection of any state $^{84}$.

\footnotetext{
${ }^{81}$ For a brief overview of the mobile courts, See The Open Society Justice Initiative's Introduction available at http://www.soros.org/initiative/justice/focus/international-justice/project/gender-justice -court; along with its reporting from the Court by Chuck Sudetic, http://blog.soros.org/2011/ 04/congo-justice-the-defendants-arrive/.

${ }^{82}$ See Piccone, (2011).

${ }^{83}$ See for instance, "The Report of the Napping Exercise documenting the most serious violations of human rights and international humanitarian law committed within the territory of the Democratic Republic of Congo between March 1993 and June 2003": August 2010, http://ww w.ohchr.org/documents/Countries/ZR/DRC-MAPPING_REPORT_FINAL_EN.pdf.p.8.

${ }^{84}$ Jallow and Bensouda (2008) at p. 16
} 
States have jurisdiction over certain offences recognized by the community of nations as of universal concern ${ }^{85}$, even where none of the usual basis of jurisdiction exists.

The trial of Adolf Eichmann ${ }^{86}$ is a well-known example of domestic courts exercising universal jurisdiction over international crimes. Eichmann was abducted from Argentina by Israeli secret police in 1960 and taken to Israel for trial. He was tried pursuant to the Israeli Nazis and Nazi Collaborators (Punishment) Law 1950, a law modelled on the 1948 Genocide Convention. Israeli Court sentenced Eichmann to death by hanging for the atrocities committed against the Jews in Europe in the years 1939-1945 ${ }^{87}$.

Also, interesting is the Demjanjuk case. Demjanjuk was extradited to Israel from America on suspicion of killing tens of thousands of people mostly Jews, by operating a gas chamber in a Nazi Concentration Camp in Poland. He was tried under Nazis and Nazi Collaboration (Punishment) Law, 1950.

However, the Israeli Supreme Court ruled that there was a reasonable doubt about Demjanjuk's guilt due to the passage of time and the spoiling of evidence ${ }^{88}$. The Supreme Court over-turned the guilty verdict and ordered Demjanjuk's release.

Another relevant case here is that of General Augusto Pinochet ${ }^{89}$. A report by the National Commission of Truth and Reconciliation (the Rettig Commission) estimated that 3.197 persons were killed and 967 disappeared during Pinochet's rule as Chilean President ${ }^{90}$. In 1998, Pinochet travelled to the UK to receive medical treatment. On 3 November 1998, Spanish Magistrate Garzon requested his extradition under European Convention on Extradition for the crimes of genocide, terrorism and torture that took place in Chile. Following the Spanish request of 16 October 1996 for

Pinochet's extradition (Pinochet had planned to leave England on 17 October) in respect of various charges introduced against him in 1996 before the Spanish Court, a British magistrate issued a warrant for his arrest. Pinochet was arrested in London on 17 October 1998.

On 14 October, 2005, The Hague District Court sentenced two Afghan asylum seekers for their role and participation in the torture of civilians during the Afghan war of $1978-1992^{91}$.

There is increased prosecutorial attention to international crimes in the Netherlands boosted by legislative reforms. Genocide, torture, war crimes and

\footnotetext{
${ }^{85}$ By their very nature, some matters are the concern of all states. In view of the importance of the rights involved all states can be said to have a legal interest in their prosecution, they are obligation erga-omnes. Barcelona Traction Case ICJ (1970) 3, para 3; Demjanvuk (1985) 603, F.Supp. 1468, Eichmann's Case (1961) 36 I.L.R.5

${ }^{86}$ Attorney General of the Government of Israel V Eichmann (1961) 36 ILR 18, 50

${ }^{87}$ A summary of Eichmann's background can be found at http://www.trial-ch.org/en/trial-wat ch-profile/db/facts/adolf-eichmann-138.html .

${ }^{88}$ Damjanjuk v Israel, Crim. App. No. 347/88 (Supreme Court July 29, 1993, http:// www.nizk or.org/hweb/people/d/demjanjuk-john/Israel-data/demjanjuk-s4.htm 1 .

${ }^{89}$ In Re-Pinochet (1999) UKHL, 1; (2000) I AC 119, 15 January, 1999.

${ }^{90}$ Jallow \& Bensouda (2008) at p. 20.

${ }^{91}$ Jallow \& Bensouda (2008) at pp 21-22. Mettraux (2006). See further District Court of the Hague, 14 October 2005, LJN: AV 489 and LJN: AV 1163)
} 
crimes against humanity among others are now criminalized under Dutch Law i.e. under International Crimes Act ${ }^{92}$.

In 1993, Belgium passed the Act Concerning the Punishment of Grave Breaches of International Humanitarian Law ${ }^{93}$. The Act accorded Belgian Courts universal jurisdiction over suspects accused of international crimes and permitted victims to file complaints in Belgium for atrocities abroad.

The accused in the case of the Bature Four were the first persons tried and convicted on the basis of this Belgian Law. The accused in the Bature four cases are - Vincent Ntezinama, Alphonso Higaniro, Consolata Mukangango and Julienne Mukabutera. The offences the four persons were accused of took place mostly in the Rwandan Prefecture of Bature. Many refugees were attacked and killed in the compound of the monastery during the conflict ${ }^{94}$. The trial before the Brussel Cour'assises, began on 17 April, 2001. The four accused were convicted on the evening of 8 June, $2001^{95}$.

Unfortunately, the Belgian Law on Universal jurisdiction has now been repealed and new legislation promulgated in its place. The new Law Belgium reduced and restricted the reach of universal jurisdiction in its Courts ${ }^{96}$.

On 3 October 2003, Adolfo Scilingo was referred for trial before a panel of judges in the Audiencia Nacional Spanish Special Court for serious international crimes.

The case was referred after Baltazan Garzon, the same Spanish investigating judge who was involved in the Pinochet case, completed his examination of crimes committed during the 'dirty war' years in Chile and Argentina between 1976 and $1983^{97}$. In 1995, Adolf Scilingo, a former Argentine Naval Officer recounted on national television in Argentina of his involvement in so-called "death-flights", in which the Navy would take live but drugged suspects into helicopter before throwing them still alive, into the River which flows through Buenos Aires. ${ }^{98}$.

After a seven year investigation, Italian authorities are seeking to prosecute former top officials in seven South American countries for their roles in Operation

\footnotetext{
${ }^{92}$ See Sections 1, 2, and 4 of International Crimes Act, Dutch Law 2003.

${ }^{93}$ Reydams (2003); Jallow \& Bensouda (2008) at p. 23.

${ }^{94}$ On 11 January, 1996, the ICTR requested Belgium to transfer the criminal proceedings to ICTR. But in a ruling dated 8 August 1996, the judges of the ICTR refused to ratify the indictment presented by the Prosecutor. Consequently, the Belgium Court of Appeal entrusted the Brussels investigation judge to continue with the inquiry into the case. See http://www.trial-ch.org/en/ trial-watch-profile/db/legal-procedures/alphouse-higaniro-163.html

${ }_{95} \mathrm{http} / / / \mathrm{www}$.trial-ch-org/en/trial-watch/profile/db/legal-procedures/alphouse-higaniro.163.html

${ }^{96} \mathrm{See}$ in this context, Arrest Warrant of 11 April 2000 (Democratic Republic of Congo V Belgium) International Court of Justice (ICJ) 14 February, 2002, In this case the ICJ found that the issuance of an arrest warrant on the basis of universal jurisdiction by Belgium for the serving Minister of Foreign Affairs of Democratic Republic of Congo was a breach of Belgium's legal obligation towards the Congo as it failed to respect the incumbent minister's immunity from prosecution. Although, the court did not expressly address the issue of universal jurisdiction. Sometime after the case, in August 2003, Belgium repealed its far reaching universal jurisdiction laws in a move that provoked a strong response from human rights organizations. See Human Rights Watch (2003). See also http://www.icj.cij.org

${ }^{97}$ Wilson (2003). See also Jallow \& Bensouda (2008) at p. 25.

${ }^{98}$ Wilson (2008).
} 
Condor, an operation in the 1970s and 1980s by the region's security forces to crush left-wing political dissent ${ }^{99}$.

Domestication and prosecution of international crimes have always been part of the domestic legislations of several African countries.

On 3 February, 2000, a court in Senegal indicted Hissene Habre, the Head of State of Chad from 1982 - 1990 for presiding over a pattern of torture during the period of his rule in Chad. Habre fled to Senegal after being overthrown in 1990 by President Idris Deby Itno ${ }^{100}$.

In July 2006, Senegal agreed to an African Union (AU) request to prosecute Habre on behalf of the $\mathrm{AU}^{101}$. This was a move warmly welcomed by the UN High Commissioner for Human Rights, Louise Arbour, who called it "a very positive development in the struggle to strengthen accountability and an important step forward in the never-ending fight against impunity.

Domesticating international crimes has always been part of Uganda. This was reflected in the Ugandan 1964 Geneva Conventions Act $^{102}$ which domesticated the 1949 Geneva Conventions ${ }^{103}$. The Act incorporates the principle of universal jurisdiction ${ }^{104}$. On 10 March 2010, the Ugandan Parliament passed the International Criminal Court Bill, which domesticated the Rome Statute. The Republic of South Africa incorporated the Rome statute into its domestic law by way of the ICC Act which entered into force on 18 July, $2002^{105}$. These crimes now form part of the South African law through the Act ${ }^{106}$.

The Rwandan government enacted the Organic Law 08/96 of 30 August, 1996 on the organization of prosecution for crimes constituting the crime of genocide, or crimes against humanity committed since 1 October, 1990. The first law to establish Gacaca Court is known as Organic Law 40/2000 of January 2011. Both the ICTR and Gacaca Courts have concurrent jurisdiction over core crimes committed on Rwandan soil by Rwandan and foreigners residing in Rwanda ${ }^{107}$.

In Democratic Republic of Congo (DRC) Military Courts have exclusive jurisdiction over genocide, war crimes and crimes against humanity perpetrated by civilian. Shortly after the DRC ratified the Rome Statute of the ICC, the Congolese Parliament amended the Country's Military Criminal Code, and granted military courts exclusive jurisdiction over international crimes ${ }^{108}$.

As a monist state, international instruments ratified by the DRC apply directly to the country as long as these are not contrary to the law and custom ${ }^{109}$. The

\footnotetext{
${ }^{99}$ Barrionuevo (2008); Jallow \& Bensouda (2008) at pp. 25-26.

${ }^{100}$ Sharp (2003). See generally, Neldjingaye (2011); Jallow \& Bensouda (2008).

${ }^{101}$ Decision on the HisseneHabre and the African Union, Assembly/AU/Dec.127 (VII).

${ }^{102}$ Geneva Conventions Act Chapter 363 Laws of Uganda 2000.

${ }^{103}$ Section 2 (1) Ibid.

${ }^{104}$ Section 2 (2) Ibid. See Mbazira (2011).

105 Stone (2011).

${ }^{106}$ Jallow \& Bensouda (2008) at p. 43. See Human Rights Watch Law and Reality (2008).

${ }^{107}$ See for instance, Father Guy Theunis, a foreigner was indicted by the Gacaca Court of genocide. See Priest faces Rwanda Genocide Trial, http:www.theage.comau/news/world/priest-faces-Rw andan-genocide-trial/2005/09/12/1126177255807.html .

${ }^{108}$ Babatunde \& Abegunde (2014).

${ }^{109}$ Articles 153 and 215 Constitution of Democratic Republic of Congo.
} 
military courts in DRC invoked the provision of the Rome statute in cases like Mbandaka, Songo Mboyo, Bongi Kahama, Bavi and Thomas Lubanga Dyilo ${ }^{110}$. The domestic implementation of the Rome Statute and the overhaul of the criminal justice system in the DRC and other African countries should be seen as a vital component of positive complementarity as it will give states the ability to have national procedures to hold accountable persons who commit crimes under the Rome Statute ${ }^{111}$.

Both Malawi ${ }^{112}$ and Zambia ${ }^{113}$ have signed and ratified the Rome Statute of the ICC. The Penal Code of Malawi ${ }^{114}$ permits Malawian courts to try crimes under the Rome Statute should the perpetrator be found in Malawi and where it is proved that the offence was committed in Malawi or partly in Malawi and partly outside Malawi.

In the case of Zambia, the Zambian Penal Code Act is the primary source of Criminal Law in Zambia. Both Malawi and Zambia could rely on International Law and the principle of universal jurisdiction to prosecute the core international crimes. Therefore, both Malawi and Zambia need to domesticate the Rome Statute as both states are dualist states ${ }^{115}$.

Nigeria ratified the Rome statute in 2001. However, the Rome Statute Bill which has been presented to the National Assembly for domestication since 2006, is yet to be enacted ${ }^{116}$.

Also, Ethiopia has domesticated the law on core international crimes. Hence, Ethiopian Federal High Court convicted former Ethiopian President Megistu Haile Marian of genocide and crimes against humanity under Article 281 of 1957 Ethiopian Penal Code ${ }^{117}$. Hissene Habre, former President of Chad is currently being held in Senegal for genocide, torture and crimes against humanity under Senegal domestic legislation. Recently, an Egyptian Court on 2 June, 2012 sentenced 84 year old former President Hosni Mubarak to life imprisonment. Former Interior Minister Habib al-Adly was sentenced for life imprisonment by the same Egyptian domestic court ${ }^{118}$.

In the United Kingdom, under Section 51(1) of the International Criminal Court Act 2001, genocide and crimes against humanity committed either in the United Kingdom or by United Kingdom (UK) national abroad can be prosecuted $^{119}$. In Canada, the Crimes against Humanity and War Crimes Act (CAHW) has incorporated the core international crimes as domestic crimes.

\footnotetext{
${ }^{110}$ Thomas Lubanga was charged under Articles 164-169 DRC Military Code.

${ }^{111}$ See generally Olugbuo (2011).

${ }^{112}$ Malawi signed the Rome Statute on 3 March, 1999 and deposited its instrument of ratification on 19 September, 2002.

${ }^{113}$ Zambia signed the Rome statute on 17 July 1999, and deposited its instrument of ratification on 19 September, 2002.

114 Chapter 7:01 Laws of Malawi

115 Nkhata (2011).

116 The PUNCH, Newspaper 31 May, 2012. See also, www.pgaction.org/.../icc/africa/ nigeria.ht ... accessed 7/9/2017

${ }^{117}$ Kebede (2007). Unfortunately, Mengistu escaped to Zimbabwe where he is presently enjoying asylum. And repeated requests for his extradition have been refused.

${ }^{118}$ Jide (2012).

${ }^{119}$ Section 51 (1) ICC Act, Laws of the United Kingdom 2001
} 
The Act also invokes universal jurisdiction as defined in Customary International Law. In France, the new Criminal Code includes a series of provisions describing crimes against humanity, genocide and war crimes as domestic crimes ${ }^{120}$.

Norwegian municipal law incorporates specific areas of International Law. Norway prosecutes international crimes using domestic penal law ${ }^{121}$. The U.S.A courts do not subscribe to the doctrine of universal jurisdiction; however, the relevant International Laws must have been incorporated directly into US Criminal Law through Congressional Legislation. Congress has enacted statutes covering genocide, war crimes, torture, piracy, slavery and trafficking in women and children to meet the US obligations under international agreements ${ }^{122}$. Germany, Spain, Sweden, Switzerland, Russia and other countries have legal instruments domesticating the core international crimes as municipal crimes ${ }^{123}$.

In 2009, a Canadian judge convicted a Rwandan of genocide. The Rwandan who entered Canada as a refugee was convicted in a Montreal Court, in Canada on seven count charge relating to the 1994 genocide in Rwandan ${ }^{124}$. The Higher Regional Court of Dusseldorf, Germany, in September 1997 handed down a genocide conviction against Nikola Jorgic, a Bosnian Serb who was the leader of a paramilitary group located in the Dobol region. He was sentenced to life imprisonment. The German Court's judgment in Nikola Jorgic was affirmed upon appeal to the European Court of Human Right (ECHR) ${ }^{125}$.

The importance of domestic enforcement and prosecution of international crimes can thus not be overestimated.

\section{Challenges Confronting the Existing Institutions}

Law through criminal prosecution and punishment of individuals for breaches of international human rights and humanitarians law by international criminal tribunals should not blind us to the basic dilemma facing international criminal justice system. Some of the challenges in this area of the law are briefly examined as follows:

State Sovereignty, for example, is a major obstacle to the effective enforcement of the principle of individual criminal responsibility and by extension the attainment of international criminal justice ${ }^{126}$. The supremacy of state sovereignty in the form of excessive restrictions on the jurisdiction of international criminal courts can only result in the creation of ineffective institutions ${ }^{127}$.

Another problem is incumbency. As long as the ideological, political and military leaders behind oppressive regimes and serious violations of international humanitarian law still remain firmly in power, flaunting with impunity their

\footnotetext{
${ }^{120}$ Article 213 of the New Criminal Code of France.

${ }^{121}$ Article 108, Norwegian Military Penal Code of 1902

${ }^{122}$ Babatunde \& Abegunde (2014) at. p. 16

${ }^{123}$ Babatunde \& Abegunde (2014) at. p. 16

${ }^{124}$ Canadian judge Convicts Rwandan of Genocide, N.Y. Times May 22, 2009

$125 \mathrm{http}: / /$ www.en.wikipedia.org.

${ }^{126}$ Ohurogu and Olagunju (2005); Bassiouni (1996); Emejuru \& Okpara (2010).

${ }^{127}$ Report of the International Law Commission, $46^{\text {th }}$ Session 1994 at 36.
} 
rendezvous with justice, this will frustrate the effort and work of international criminal tribunals and justice system. So long as states retain some aspects of the sovereignty and fail to set up an effective mechanism to enforce arrest warrants and to execute judgments, international criminal tribunals may have little more than normative impact.

Again, there is the problem/danger posed by international politics ${ }^{128}$. The effective operation of international criminal courts depends on the unstable reserve of political will, especially in the world capitals. Without the cooperation and support of individual states, international courts are doomed to impotence, for example, they have no power to arrest or, compel the production of evidence, nor to enforce judgment. For these reasons alone, a rigorous system for the rule of law cannot at present be established, and justice cannot meaningfully be administered without regards to the volatile and complex world of international politics. Powerful actors in international arena are in position to ignore the demands of international courts, and the sword of justice tends to be used most against individuals from states that occupy a lowly place in the de-facto existing hierarchy of states.

Also, germane for consideration is the dearth of resources, fund and other logistic and technical problems which constitute serious impediments to effective performance of the international judicial mechanisms ${ }^{129}$. Closely related to the foregoing is lack of judicial bravery and independence as displayed in the case of Jean Bosco Baragawiza before the International Criminal Tribunal for Rwanda in $1999^{130}$.

Other challenges, however, exist which include: corruption (in all its forms and ramifications, at national level and beyond), scourge of terrorism which is ravaging and afflicting every nation today, amnesty law, asylum and extradition practice, limited jurisdiction of the ICC and so on.

Some states chose to deal with their past human rights atrocities by enacting amnesty laws which have the effect of barring proceedings against the perpetrators of such crimes, thus leaving them unpunished ${ }^{131}$. Again, individual accused of international atrocities are granted frivolous and questionable asylum which ought not to be and so make mockery of the law ${ }^{132}$. Shielding of criminal is condemnable. Hence, any country that shield criminal from prosecution should be severely sanctioned, by the UN and the international community, while extradition or surrendering of fugitive should be embraced and harnessed

\footnotetext{
${ }^{128}$ Megret (2002); Bassiouni (1996); Damaska (2008); Moghalu (2005).

${ }^{129}$ Aragao (2005) at pp. 8-9.

${ }^{130}$ Prosecutor v Barayawiza, Case No. ICTR-97-19 Ar 72 Decision of $3^{\text {rd }}$ November 1999, pp. 46; see Schabas (2000).

${ }^{131}$ See the interesting decision for the Constitutional Court of South Africa of 25/6/1996 in Azanian Peoples Organizations v President of the Republic of South Africa, case CCT 17/96, comment by Wilhelm in 91 AJIL (1997) 360, upholding the constitutionality of the promotion of National Unity and Reconciliation Act 1996. Surely, however, there is no duty by other state to recognize such laws, nor would a defence based on them be likely to succeed before an international criminal tribunal or a foreign domestic court. See Orentlicher (1991); See also Nino (1991).

${ }^{132}$ Adedamola (2005) at p. 34
} 
positively ${ }^{133}$. The foregoing challenges among others must be overcome, cooperatively, because we now live in a global village, (as it is often said), otherwise, the efforts and resources already invested (and still being invested) in the fight against impunity will be an exercise in futility.

\section{Prospects of Prosecuting Individual for International Crimes}

Individual Criminal Responsibility has several prospects, some of which are itemized below:

- Strengthening Shift from Impunity to Accountability.

- Strengthening the Jurisprudence of International Criminal Justice

- Strengthening Universality and Discouraging Strict Adherence to the Doctrine of State Sovereignty.

- Strengthening the rule of law.

- Strengthening justice for atrocity; strengthening restoration of peace.

- Helping to achieve not only a sense of justice, but, eliminating a sense of injustice.

- Strengthening deterrence of further or future crimes and so on.

\section{Concluding Remark and Recommendation}

This paper has thoroughly x-rayed the institutional framework for individual criminal responsibility under international law. It has also examined the prosecution of individual before domestic courts for violation of international law. Also, this paper appraised some inherent challenges as well as prospects of the principle of individual criminal responsibility. This paper revealed the importance of domestic enforcement and prosecution of international crimes cannot be over-estimated. It also revealed that despite a plethora of legal and institutional framework on this area, it is not yet Uhuru. It is thus hoped that the analysis above has thrown some light on the grey area hitherto bedevilling this area of the law.

The following recommendations are hereby proffered:

- States need to cooperate and show readiness and willingness to discharge their obligation to prevent crime, arrest, prosecute or extradite a criminal or fugitive within their territories.

- States should honour their obligations under customary international and under treaty, especially human rights treaties States.

${ }^{133}$ Abegunde (2011); Babatunde (2010). 
- States should take measures that prevent impunity and promote accountability, such as refusal to grant amnesty, removal of immunity clauses etc.

- States should support the existing national, regional, international institutions, financially, materially, technically and so on.

- The existing institution should collaborate with one another and complement one another in information sharing and dissemination.

- National, regional and international civil society groups should continue to build and strengthened international justice.

- It also recommended that democratization of Governance across the globe is a new road to peace and stability.

- There is also a need for the establishment of a supra-national judicial institution as against the caricature called International Criminal Court. (ICC).

- Corruption and Terrorism are the two greatest problems bedevilling the world today, hence, the need for States to double up their efforts in this regard.

\section{References}

Abegunde, B. (2011). 'Law and Practice of Extradition under International Law. A Critical Appraisal', in Essays in Honour of Prof Akin Oyebode, published by Jurist Consult, 8: 1-35.

Adedamola, K. (2005). 'Accountability for War Crimes, the Concept of Asylum and the Charles Taylor Saga: Issues and Challenges', Ikeja Bar Journal, 1(2):26-34.

Aragao, E.J.G. (2005). 'Setting Standards for Domestic Prosecution of Gross Violations of Human Rights through the ICC: International Jurisdiction for willing killing in Brazil? Challenges and Prospects', Proceedings of an Int'l Conference organized by the European Inter-University Centre for Human Rights Democratisation, (EIUC) Venice.

Babatunde, I.O. (2010). 'Extradition in International Law: Ibori's Conundrum', UNAD L.J. 3:60-78.

Babatunde, I.O. and B. Abegunde (2014). 'Investigating and Prosecuting International Crimes Domestically: Rethinking International Criminal Law', Global Journal of Law and Politics, 2(3):64-76.

Bass, G.J. (2000). Stay the Hand of Vengeance: The Politics of War Crimes Trials. Princeton University Press. Princeton, NJ. USA

Bassiouni, M. C. (1996). 'Accountability for Violation of International Humanitarian Law and Other Serious Violations of Human Rights', Law and Contemporary Problems 59:23.

Barrionuevo, A. (2008), 'Italy follows Trial of Secret South American Abductions', New York Times, 2008, 22 January p. 8.

Bhoke, C. (2008). 'The Trial of Charles Taylor: Conflict Prosecution, International Law and Impunity-free Africa', in Menon, A.V. (ed) War Crimes and Law, pp. 174-215.

Carter, B.E. \& P.R. Trimble (1995). International Law, $2^{\text {nd }}$ ed. Aspen Law \& Business 
Cavallaro, J.L. \& S.E. Brewer (2008). "Re-evaluating Regional Human Rights Litigation in the Twenty-First Century: The Case of the Inter-American Court", A.J.I.L., 102:768-827.

Damaska, M. (2008). 'What is the Point of International Criminal Justice', Yale Law School Faculty Scholarship Series, Paper 1723, at http;//digitalcommons.law.ya le.edu/fsspapers/, also published in Heinonline(2008) Chi-kent. L. Rev. 83:329-365.

Danner, A.M. \& J. Martinez (2005), "Guilty Association: Joint Criminal Enterprises Command Responsibility, and the Development of International Criminal law", Cal. L. Rev. 93: 67.

Deen-Racsmany,Z. (2005). 'Prosecutor v Taylor: The Status of the Special Court for Sierra-Lone and its Implications for Immunity', Leiden J. Int'l L. 18:299-322.

Del Ponte's November 2000 Address to the United Nations Security Council, Prosecutor to ICTY No. 2001, New York.

Emejuru, C. T. and J.O. Okpara (2010). 'The Fundamental Doctrine of Immunity of Heads of Foreign States: An Appraisal.' EBSU J. Int'l L. \& Jur. Rev. 1: 106-118.

Fact Sheet on the ICTY Proceedings, December 29, 2003.

Gallagher, K. (2005). "International Criminal Tribunal for the former Yugoslavia, The Second Srebrenica Trial: Prosecutor v Vidoje Blagojevic and Dragan Jokic', Leiden J. Int'L 18(3): 515 - 532.

Government of Sierra-Leone 'Truth and Reconciliation Commission Report (2004).

Hagan, J., Levi, R. \& G. Ferrales (2006). 'Swaying the Hand of Justice: The Internal and External Dynamics of Regime Change at the International Criminal Tribunal for the former Yugoslavia', Law and Social Inquiry, 31(3): 585 - 616.

Human Rights Watch Report on Rwandan Genocide (2008), http://www.org/reports/ 1999/rwanda/genoc.1-3-01-htm

Human Rights Watch (2011). 'Libya: African Rights Court Issues first Ruling Against a State', March 30, 2011, http://www.hrw.org/en/news/2011/03/30/libya-africanrights-court-issues-first-ruling-against-state.

Jallow, H. \& F. Bensouda, (2008). 'International Criminal Law in an African Context,' in Du-Plessis, M., (ed) African Guide to International Criminal Justice, Institute for Security Studies, Pretoria.

Jide, O. (2012). 'Taylor, Mubarak and Lessons for African Leaders', in PUNCH Newspaper, Monday July 2, 16.

Kaye, D.A. 2011). 'Justice Beyond the Hague: Supporting the Prosecution of International Crimes in National Courts', Council Special Report, 61:9-10.

Kebede, T.F. (2007). 'The Mengistu Genocide Trial in Ethiopia'. Journal of Int'l Crim. Just. 23.

Maga, T.P. (2001). Judgment at Tokyo: The Japanese War Crimes Trials, University Press of Kentucky, USA.

Mbazira, C. (2011). 'Prosecuting International Crimes Committed by the Lord's Resistance Army in Uganda', in C. Marungu \& J. Beigon (eds) Prosecuting International Crimes in African Pretoria, pp. 197-220. Pretoria University Law Press.

Megret, F. (2002). 'The Politics of International Criminal Justice', E.J.I.L 13:1262.

Mettraux, G. (2006), "Dutch Court's Universal Jurisdiction over Violations of Common Article 3 qua War Crimes". Journal of Int'l Crim Justice, 362.

Moghalu, K.C. (2005). Rwandan Genocide: The Polictics of Global Justice, Palgrave Macmillian.

Mugwanya, G.W. (2006). 'Criminal Justice through International Criminal Tribunals: Reflections on some Lessons for National Criminal Justice Systems', African Human Rights Law Journal, 6(1):26-63. 
Murungu, C., (2011) 'Prosecution and Punishment of International Crimes by the Special Court for Sierra Leon', in C. Murungu \& J. Biegon (eds), Prosecuting International Crimes in Africa. Pretoria University Law Press.

Neldjingaye, K., (2011) "The Trial of HisseneHabre in Senegal; and Its Contribution to International Criminal Law" in C. Murungu \& J. Biegon (eds), Prosecuting International Crimes in Africa, pp. 185-192. Pretoria University Law Press.

Nino, C.S. (1991). 'The Duty to Punish Past Abuses of Human Rights Put in Context: The Case of Argentina' Yale L.J. 100:2619.

Nkhata, M. (2011) "Implementation of the Rome Statute in Malawi and Zambia: Progress Challenges and Prospects", in Prosecuting International Crimes in Africa, pp. 222-302. Pretoria University Law Press.

Nouwen, S.M.H., (2005), "The Special Court for Sierra-Leone and the Immunity of Taylor: The Arrest Warrant Case Continued", Leiden J. Int'l L. 18(3): 645-669.

Olugbuo, B., (2011), 'Positive Complementarity and the Fight Against Impunity in Africa', in C. Murungu \& J. Biegon (eds) Prosecuting International Crimes in Africa, pp. 249-274. Pretoria University Law Press.

Ohurogu, C.C. and A.G. Olagunju (2005). 'Fostering International Peace and Security: The Different Facets of Peace Process and the Continuing Challenges of the United Nations', in Goubadia, D.A. \& E. Azinge, (eds) Globalization National Development and the Law, being paper presented at the National Association of Law Teacher (NALT) Conference, Lagos, pp.332-357.

Orentlicher, D.F. (1991). 'Settling Accounts: The Duty to Prosecute Human Rights Violations of a Prior Regime' Yale L.J. 100:2537-2615.

Oyebode, A. (2011), 'Of Norms, Values and Attitudes: The Cogency of International Law, 'An Inaugural Lecture Delivered at the University of Lagos Main Auditorium on Wednesday $7^{\text {th }}$ December, 2011. http://repository.unilag.edu.ng/xmlui/handle/ $123456789 / 533$

Pritchard, R. J. and S. M. Zarde (1981), The Tokyo War Crimes. Trial, Vol. 1, New York and London, Garland Publishing Inc.

Piccone, T. (2011), 'The Contribution of the UN' Special Procedures to National Level Implementation of Human Rights Norms', International Journal of Human Rights 15:206-231.

Reydams, I. (2003) "Belgium's first Application of Universal Jurisdiction: The Butare Four Case", Journal of International Criminal Justice 1:429-430.

Schabas, W.A. (2000). 'International Decision: Baragawiza v Prosecutor," A.J.I.L, 94:563

Sharp, D. (2003). 'Prosecutions, Development and Justice: The Trial of Hissein Habre', Harvard Human Rights Journal, 16:148-149.

Stahin, C. (2005). 'The Geometry of Transitional Justice: Choice of Institutional Design', Leiden J. Int'l L. 18(3):424-466.

Stone, L. (2011). 'Implementation of the Rome Statute of the ICC in South Africa'. in Murungu, C., \& Biegon, J., (eds), Prosecuting International Crimes in Africa, pp. 305-330. Pretoria University Law Press.

The Open Society Justice Initiative's Introduction available at http://www.soros.org/ initiative/justice/focus/international-justice/project/gender-justice-court.

Unger, R.M. (1976). Law in Modern Society. Toward a Criticism of Social Theory. The Free Press, New York, NY, USA

Willis, J.F. (1982). Prologue to Nuremberg - The Politics and Diplomacy of Punishing War Criminals of the First World War, West Port, London: Greenwood Press.

Wilson, R. (2003). 'Argentine Military Office Face Trial in Spanish Court', ASIL Insights. Available at http://www.asil.org/insights/insigh 122.html 
Wilson, R. (2008). 'Spanish Supreme Court affirms Conviction of Argentine former Naval Officer for Crimes against Humanity', ASIL Insights, 12 (1) 30 January 2008. Available at http://www.asil.org/ insights/2008/01/insights080130.html

\section{Cases}

Arrest Warrant of $11^{\text {th }}$ April 2000 (Democratic Republic of Congo $v$ Belgium) International Court of Justice (ICJ) 14 February, 2002.

Attorney General of the Government of Israel v. Eichmann (1961) 36 ILR 18, 50.

Barcelona Traction Case ICJ (1970) 3, para 3.

Demjanvuk (1985) 603, F.Supp. 146.

Damjanjuk v. Israel, Crim. App. No. 347/88 (Supreme Court July 29, 1993, http://www. nizkor.org/hweb/people/d/demjanjuk-john/Israel-data/demjanjuk-s4.html.

In Re-Pinochet (1999) UKHL, 1; (2000) I AC 119, 15 January, 1999.

Prosecutor v Endemovic, Case No IT-96-22-A.

Prosecutorv Tadic case No IT-94-1 Appeal Chambers 15 July, 1999

Prosecutor v Mrdja case No IT-02-59-S. Trial Chambers, 31 March, 2004.

Prosecutor v Blagojevic and Jokvic Case No IT-02-60 Trial Judgment,

Prosecutor v Akayesu, Case No ICTR-96-4-T delivered 2 September, 2008.

Prosecutorv Jean Kambanda, Case No ICTR 97-23.S. delivered on 4 September, 2008

Prosecutor v Rutagand, Case ICTR-96-3. Judgment Sentence 6 December 1999.

Prosecutor $v$ Kayishema and Ruzindana case ICTR-95-I-T Judgment and Sentence 21 May 1999.

Prosecutor v Kunarac case IT-96-23 Appeal 12 June, 2002.

Prosecutor v Muhimana, Case ICTR-95-13-T. J.

Prosecutor v Gacumbits, Case ICTR-2001-64-A, Judgment 7 July 2006.

Prosecutor v Norman, Fofana and Kondewa case SCSL-04-14-T

Proseuctor v Koroma (Case SCSL-03-03.

Prosecutorv Bockarie (case SCSL 03-04).

Prosecutor v Sankoh (Case SCSL-03-02).

Prosecutor v Sesay (case SCSL-03-05).

Prosecutor v Kallon (case SCSL-03-07).

Prosecutor v Gbao (case SCSL-03-09).

Prosecutor v Taylor (Case SCSL-03-01.

Prosecutor v Sesay, Kallon, and Gbao, Revolutionary United Front (RUF) Trial (case SCSL-04-15-PT) 13 May, 2004.

Prosecutor v Brima, Kamara and Kanu, AFRC Trial (Case SCSL-2004-16-PT) 18 February 2005.

Prosecutor v Taylor (case SCSL-2003-01-1), 3 March 2003

Prosecutor v Fofana \& Kondewa (Case SCSL-04-14-A) Appeal Judgment 28 May, 2008 Para 1-10. (http://www.sc-sl.org/CDF-Trial.html)

Prosecutor $v$ Wiranto et al, Indictment, p. 36 UN MISET (Special Panel for Serious Crimes, Feb. 22, 2003).

Prosecutor v Sormento et al, Indictment II, August 7, 2001, available at http://www.js mp.minihub.org/courtmonitoring/spsccaseinformation2000.htm.

Prosecutor v Dyilo Lubanga, ICC-01/04-01/06, 29 January, 2007, para 261 - 263, available at http://www.lubangatrial.org/2012/06 
